\title{
SUBURBAN VS. URBAN FRINGES ENTITIES' WILLINGNESS TO PAY FOR AMENITIES: EMPIRICAL RESEARCH IN CRACOW CITY, POLAND
}

\author{
Piotr LITYŃSKI \\ Cracow University of Economics, Poland
}

\begin{abstract}
The aim of this paper is to estimate the value of selected amenities of infrastructure, space and public services on both sides of the cities' administrative borders and its territorial implications. The used method is the estimation of WTP. The method was addressed to households and companies located in the district adjoining areas which are administratively not part of the city, and that are judged to be strongly characterized by the processes of suburbanization. The conclusions of the study indicate that the administrative border of the city is polarized in terms of a household economic profile. Residents of both regions express their needs for amenities and suburban residents generally estimate their value higher. While firms from both areas are not interested in improvements, the administrative border of the city does not really differentiate businesses (size, employment, wages).
\end{abstract}

Key Words: WTP, amenities, valuation, public services, space, infrastructure

\section{Introduction}

Strong social and economic transformation in cities of development and developing countries involve the need of urban policy in an efficient manner to stimulate further development (Parysek 2010). Therefore, despite the existing land development in cities and their surroundings, policy makers are forced to seek paths of wider improvement of amenities for businesses as well as population. These amenities are understood both as physical elements such as: space, roads, parking lots, schools, but also as desirable from the standpoint of the development of such phenomena as: higher public safety, improved environmental quality, shorter travel time to a selected destination (Deller et al. 2001, Green 2001).

Evaluations of impact on the development of local amenities have been present in the literature for forty years. By the end of the 1990s the study of effects on the development of local amenities were limited to the analysis of individual measures, e.g. water and air pollution. In the 1990 s empirical research began to explore the roles of a wider range of amenities (Waltert and Schläpfer 2010). At this time suburban amenities gained interests in public policy as a factor of life quality and business location decision (Beyers and Lindahl 1996, Cavailhes et al. 2004, Gottlieb 1995, Johnson and Rasker 1993). In rural areas, local authorities have begun to support the development of amenities which may result in several studies conclusion that amenities (eg. Environmental amenities) are a factor of rural development (Green 2001, Deller et al. 2001, Feinerman and Komen 2003, Fuller et al. 2005).

Wider impact of local amenities on the local economy today is discernible in many studies. Waltert and Schläpfer (2010) have made extensive review of the literature on the role of the amenities in economic change. They identified that amenities affect the economy through the impact on: demography, employment, income, rents, wages and property values. They conclude that economies of amenity-rich areas tend to grow faster in terms of population and 
property values then other areas while the link between amenities, employment and income is inconsistent: some research showed positive and significant impact, some non-significant and a few negative impact (Waltert and Schläpfer 2010). However, there are studies showing the positive effects of the amenities occur more frequently in the suburban and urban rather than rural areas (Chay and Greenstone 2005, Redfearn 2009). Parallel to positive effects of amenities occurring in the suburban areas there are also some perceived negatives: there have been proven important links between the existing local amenities and spatial development patterns in both size of cities: urban and rural (Wu and Gopinath 2008). They proved amenities as determinates of phenomena like urban sprawl and leapfrog effect. The explanation of defects amenities are represented by the consumer preferences for large plots of land, open spaces which are attracted by the suburbia rich in such spatial amenities (Chen et al. 2009).

Economic research has focused on the monetary valuation of amenities through surveys using the willingness to pay method (Bergstrom and Ready 2009). A lot of research contributes to understanding the impact of amenities for local development (Matsuoka and Kaplan 2008, Banzhaf 2010, Milburn et al. 2010). However, many studies related to the willingness to pay for amenities show that it is not affiliated with the needs of policy makers in land planning (Banzhaf 2010). Therefore, in the literature we recognize the need for further study using approaches that take political responses to amenity into account (Chen et al. 2009, Nelson et al. 2007, Walsh 2007).

Since we know that the existing amenities are important in economic development on the one hand, on the other hand we are facing economic downturn while an improvement of the amenities is inextricably linked to the occurrence of this development at a higher level. So for the urban policy makers the question is: what are the values of the improvement of existing amenities and the legitimacy of these improvements? While the valuation of certain physical features of space can be related easily from the supply side, e.g. the ease of construction of a new road pricing by the office of the municipality, on the demand side, this valuation can be problematic. An even greater challenge holds the pricing phenomena, e.g. reduction of travel time between points in the city or improved air quality.

With this in mind, the aim of the present study is to show an attempt to estimate the value of the selected amenities from the point of view of the major actors of the real economy on both sides of the administrative border of the city using the example of Cracow. At the same time the assessment of the valuation amenities will be carried out in terms of their usefulness for policy makers or taking into account the territorial implications. The study presents in itself an inference on amenities in the spatially close areas, neighboring metropolitan areas within the administrative boundary but being separated by the central city. The choice of the study area was dictated by the fact that: a) modern urban development is inextricably linked with the process of suburbanization (Parysek 2010); b) there are city areas that have been neglected by the planning processes and by academic research and these areas are represented by the urban fringes (Gilhespy 2013).

\section{Materials and Methods}

The Contingent Valuation Method (CVM) next to the Travel Cost Method and the Hedonic Prices Methods is the most common approach in estimating the values of the various elements of space, infrastructure or public services. While the hedonic pricing method and travel costs are based on the observation of market prices of goods associated with the rated good, CVM is based on a hypothetical market (Żylicz 2004). This feature is important for estimating the value of the amenities in respect to the area that could potentially arise and which are the subject of the article.

CVM has a long tradition and its origins date back 40 years of the last century (Carson 2007). 
CVM strongly developed in the seventies and eighties, particularly in relation to the valuation of valuable natural areas and a variety of environmental values (Green and Blair 1995). This method is well adapted to estimate the value of other non-market goods. The use of CVM also valued environmental damage caused by natural disasters or the realization of certain projects (Johansson 1990, Winpenny 1995). CVM is also used to estimate the ex-ante evaluation of the benefits of the infrastructure investments financed by the European Union.

The development of CVM increases its applications in various fields, e.g.: evaluation of public services, the evaluation of the environmental, cultural activities, recreational services, valuation of monuments and works of art, people's landscape needs and preferences, locations decisions (Huhtala 2004, Noonan 2004, Matsuoka and Kaplan 2008, Banzhaf 2010, Milburn et al. 2010).

CVM is a method based on the results of a survey. The survey questions are formulated in the form of a hypothetical desire by the respondent to indicate which payment for the selected good or service (WTP - called Willingness to Pay). This method is referred to as "conditional" because the good or service, in fact, will not necessarily be delivered. Answers to such questions can be formulated either in the form of specific amounts or an answer "yes/no", where the search for the WTP amount shall be an econometric analysis (Diamond and Hausman 1994, Bateman and Langford 1997, Pearce 1993).

The subject of this study accounts the selected types of amenities gathered in three groups: infrastructure, space and public services. In the first group, i.e. infrastructure, amenities include the shortening distance to destinations, increasing the number of roads in the area, accessibility or improvement of an infrastructure element. The second group, i.e. the space, amenities such as enlarged functional area (residential or business), access to public spaces, access to natural open space, an environment of higher quality (e.g. air). The third group of amenities, i.e. public services, is associated with: better education and health care, higher public safety. It should be noted that these amenities are on the one hand close to the respondents, and on the other hand they refer to the range of CVM application areas indicated in the literature. From this perspective, it seems that the WTP method of estimating the proper amenity is undertaken in the present study.

The study subjects were addressed to businesses and households. The area of study includes the selected districts of the City of Cracow (Poland), which is located on the administrative borders of the City (two districts: Prądnik Czerwony and Prądnik Biały) and the area directly across the border of the City, which belongs to the Municipality Zielonki. This area is one of the Cracow Metropolitan Area (CMA). Thus, the analysis area includes the land and space on both sides of the border city. The area covered by the analysis is shown in Fig. 1.

Estimating the value of these amenities reveals the balance of the needs of both level and potential value. In contrast, the types of adopted amenities were collected in three groups that arise from the urge to identify the needs of stakeholders on both sides of the border of the city and to identify the similarities and differences of these two adjacent areas.

The test results are based on the two types of surveys carried out in the indicated area. The first type of the survey was addressed to residents on both sides of the border of Cracow, while the second type of the survey was addressed to businesses in the same area. Surveys include questions with open answers - they are not a set of answer options provided for the respondents. The details of the respondents' profiles are given in Table 1. 


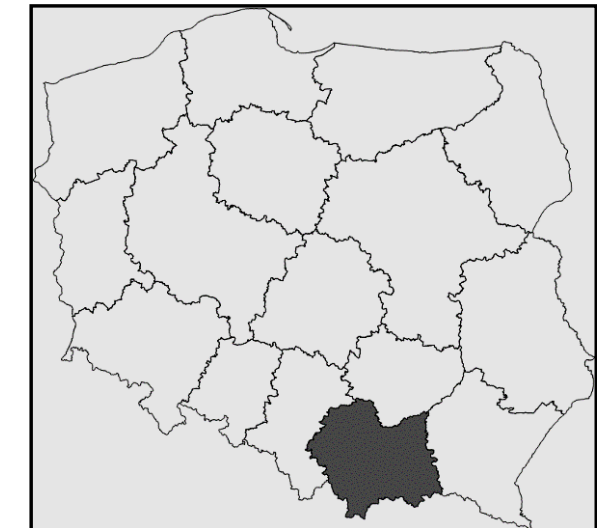

a)

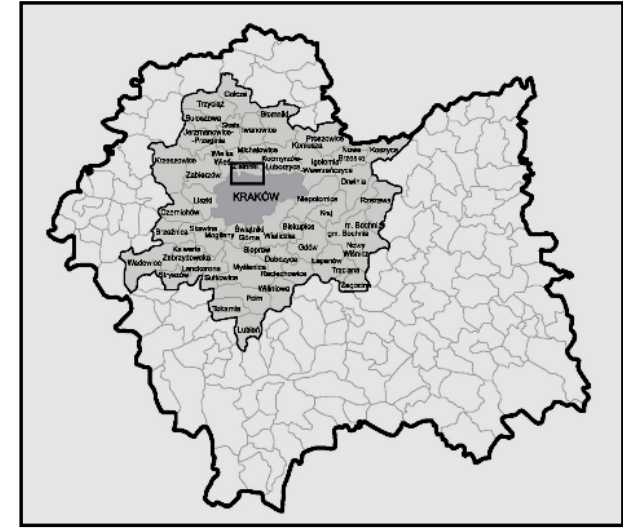

b)

Fig. 1 - The area covered by the analysis

a) Poland and Małopolska Region; b) City of Cracow in the Cracow Metropolitan Area and the Malopolska Region

Characteristics of the surveyed residents and businesses

Table 1

\begin{tabular}{|c|c|c|c|c|c|}
\hline Households & Cracow & $\begin{array}{c}\text { Zielonki } \\
\text { (suburbs) }\end{array}$ & Businesses & $\begin{array}{c}\text { Cracow } \\
\text { City }\end{array}$ & $\begin{array}{r}\text { Zielonki } \\
\text { (suburbs) }\end{array}$ \\
\hline $\begin{array}{l}\text { Number of } \\
\text { surveyed residents } \\
\text { [pp.] }\end{array}$ & 764 & 578 & $\begin{array}{l}\text { Number of surveyed busi- } \\
\text { nesses [unit] }\end{array}$ & 185 & 96 \\
\hline $\begin{array}{l}\text { Number of re- } \\
\text { sponses [pp.] }\end{array}$ & 154 & 127 & $\begin{array}{l}\text { Number of responses } \\
\text { [unit] }\end{array}$ & 75 & 37 \\
\hline Age & & & Form of economic activity & & \\
\hline average [years] & 40 & 42 & manufacturing [\%] & 0 & 14 \\
\hline Q1 [years] & 32 & 35 & services and retail [\%] & 100 & 86 \\
\hline Q2 [years] & 41 & 40 & Trade & & \\
\hline Q3 [years] & 58 & 48 & food [\%] & 29 & 14 \\
\hline Marital Status & & & clothing [\%] & 10 & 0 \\
\hline married [\%] & 73 & 95 & car service $[\%]$ & 10 & 19 \\
\hline single $[\%]$ & 27 & 5 & medical and cosmetic [\%] & 10 & 6 \\
\hline Number of children & & & household goods [\%] & 13 & 8 \\
\hline average [pp.] & 1 & 2 & legal and financial [\%] & 4 & 17 \\
\hline median [pp.] & 1 & 2 & construction [\%] & 4 & 6 \\
\hline $0[\%]$ & 20 & 14 & restaurants [\%] & 4 & 6 \\
\hline $1[\%]$ & 33 & 24 & gardening [\%] & 2 & 6 \\
\hline $2[\%]$ & 41 & 40 & educational [\%] & 0 & 8 \\
\hline $3[\%]$ & 4 & 20 & other $[\%]$ & 13 & 11 \\
\hline $4[\%]$ & 2 & 2 & Employees & & \\
\hline Occupation & & & average [pp.] & 3 & 4 \\
\hline lawyers [\%] & 2 & 2 & $\min .[p p]$. & 1 & 1 \\
\hline doctors [\%] & 3 & 8 & max. [pp.] & 15 & 12 \\
\hline $\begin{array}{l}\text { business } \\
\text { owners [\%] }\end{array}$ & 4 & 18 & Salary & & \\
\hline officials [\%] & 13 & 11 & average $[€]$ & 470 & 522 \\
\hline
\end{tabular}


Suburban vs. Urban Fringes Entities' Willingness to Pay for Amenities: Empirical Research in Cracow City, Poland

Characteristics of the surveyed residents and businesses

Table 1

\begin{tabular}{|l|c|c|l|c|c|}
\hline Households & Cracow & $\begin{array}{c}\text { Zielonki } \\
\text { (suburbs) }\end{array}$ & Businesses & $\begin{array}{c}\text { Cracow } \\
\text { City }\end{array}$ & $\begin{array}{c}\text { Zielonki } \\
\text { (suburbs) }\end{array}$ \\
\hline specialists [\%] & 28 & 25 & min.[€] & 202 & 289 \\
\hline workers [\%] & 30 & 19 & max.[€] & 723 & 771 \\
\hline pensioners [\%] & 15 & 3 & $M[€]$ & 482 & 482 \\
\hline unemployed [\%] & 5 & 14 & & & \\
\hline Monthly earnings & & & & & \\
\hline average [€] & 1320 & 1984 & & & \\
\hline$M[€]$ & 1084 & 1928 & & & \\
\hline
\end{tabular}

\section{Results and Discussion}

Results of the survey are presented in Tables 2 and 3.

Table 2

Willingness to pay for amenities expressed by the households

\begin{tabular}{|c|c|c|c|c|c|c|c|c|}
\hline Amenities & $\mathrm{N}$ & $\mathrm{n}$ & $\begin{array}{l}\text { Share } \\
\text { "No" }\end{array}$ & $\begin{array}{l}\text { Share } \\
\text { WTP }\end{array}$ & $\dot{\mathrm{X}}$ & M & $\sigma$ & $\mathrm{D}$ \\
\hline \multicolumn{9}{|c|}{ Cracow City } \\
\hline 1. Reduced travel time & 57 & $37 \%$ & $39 \%$ & $61 \%$ & $€ 39$ & $€ 19$ & $€ 85$ & $€ 24$ \\
\hline The value of time spent in traffic jams in min. & 28 & $18 \%$ & $0 \%$ & $100 \%$ & $€ 0.06$ & $€ 0.02$ & $€ 0.07$ & $€ 0.04$ \\
\hline Reduced in relation to monthly earnings & 18 & $12 \%$ & $0 \%$ & $100 \%$ & $1.44 \%$ & $0.95 \%$ & $1.29 \%$ & $0.50 \%$ \\
\hline $\begin{array}{l}\text { Reduced in relation to expenditure on fuel } \\
\text { and tickets }\end{array}$ & 33 & $21 \%$ & $0 \%$ & $100 \%$ & $28 \%$ & $19 \%$ & $30 \%$ & $100 \%$ \\
\hline 2. More roads in the area & 70 & $45 \%$ & $23 \%$ & $77 \%$ & $€ 13$ & $€ 12$ & $€ 11$ & $€ 12$ \\
\hline More roads in relation to earnings & 27 & $18 \%$ & $0 \%$ & $100 \%$ & $1.12 \%$ & $0.91 \%$ & $0.84 \%$ & $2.50 \%$ \\
\hline 3. Larger homes & 55 & $36 \%$ & $53 \%$ & $47 \%$ & $€ 109$ & $€ 12$ & $€ 314$ & $€ 12$ \\
\hline Larger homes in relation to earnings & 12 & $8 \%$ & $0 \%$ & $100 \%$ & $2.18 \%$ & $1.43 \%$ & $2.17 \%$ & $0.83 \%$ \\
\hline 4. Access to public spaces & 47 & $31 \%$ & $57 \%$ & $43 \%$ & $€ 9$ & $€ 5$ & $€ 9$ & $€ 2$ \\
\hline $\begin{array}{l}\text { Access to public spaces in relation to earn- } \\
\text { ings }\end{array}$ & 10 & $6 \%$ & $0 \%$ & $100 \%$ & $0.85 \%$ & $0.50 \%$ & $0.97 \%$ & $0.50 \%$ \\
\hline 5. Access to nature & 51 & $33 \%$ & $45 \%$ & $55 \%$ & $€ 10$ & $€ 5$ & $€ 8$ & $€ 2$ \\
\hline Access to nature in relation to earnings & 13 & $8 \%$ & $0 \%$ & $100 \%$ & $0.84 \%$ & $0.63 \%$ & $0.69 \%$ & --- \\
\hline 6. Better environment & 63 & $41 \%$ & $35 \%$ & $65 \%$ & $€ 11$ & $€ 12$ & $€ 9$ & $€ 12$ \\
\hline Better environment in relation to earnings & 23 & $15 \%$ & $0 \%$ & $100 \%$ & $1.08 \%$ & $0.91 \%$ & $0.88 \%$ & $1.67 \%$ \\
\hline 7. Better education and health care & 77 & $50 \%$ & $32 \%$ & $68 \%$ & $€ 15$ & $€ 10$ & $€ 14$ & $€ 24$ \\
\hline Better service in relation to earnings & 29 & $19 \%$ & $0 \%$ & $100 \%$ & $1.71 \%$ & $1.43 \%$ & $1.40 \%$ & $0.50 \%$ \\
\hline 8. Higher public safety & 70 & $45 \%$ & $31 \%$ & $69 \%$ & $€ 11$ & $€ 12$ & $€ 8$ & $€ 12$ \\
\hline Higher public safety in relation to earnings & 28 & $18 \%$ & $0 \%$ & $100 \%$ & $0.87 \%$ & $0.67 \%$ & $0.67 \%$ & $0.83 \%$ \\
\hline \multicolumn{9}{|c|}{ Zielonki Municipality } \\
\hline 1. Reduced travel time & 76 & $60 \%$ & $18 \%$ & $82 \%$ & $€ 34$ & $€ 24$ & $€ 66$ & $€ 24$ \\
\hline The value of time spent in traffic jams in min. & 71 & $56 \%$ & $20 \%$ & $80 \%$ & $€ 0.09$ & $€ 0.04$ & $€ 0.17$ & $€ 0.02$ \\
\hline Reduced in relation to monthly earnings & 49 & $39 \%$ & $29 \%$ & $71 \%$ & $2.23 \%$ & $1.50 \%$ & $2.93 \%$ & $1.67 \%$ \\
\hline $\begin{array}{l}\text { Reduced in relation to expenditure on fuel } \\
\text { and tickets }\end{array}$ & 74 & $58 \%$ & $19 \%$ & $81 \%$ & $28 \%$ & $12 \%$ & $47 \%$ & $5 \%$ \\
\hline 2. More roads in the area & 67 & $53 \%$ & $31 \%$ & $69 \%$ & $€ 29$ & $€ 12$ & $€ 56$ & $€ 12$ \\
\hline More roads in relation to earnings & 26 & $20 \%$ & $0 \%$ & $100 \%$ & $1.98 \%$ & $0.83 \%$ & $3.18 \%$ & $0.50 \%$ \\
\hline 3. Larger homes & 66 & $52 \%$ & $45 \%$ & $55 \%$ & $€ 202$ & $€ 24$ & $€ 801$ & $€ 24$ \\
\hline Larger homes in relation to earnings & 25 & $20 \%$ & $0 \%$ & $100 \%$ & $5.02 \%$ & $1.63 \%$ & $7.26 \%$ & $1.00 \%$ \\
\hline
\end{tabular}




\section{Piotr LITYŃSKI}

\section{Willingness to pay for amenities expressed by the households}

\begin{tabular}{|c|c|c|c|c|c|c|c|c|}
\hline Amenities & $\mathrm{N}$ & $\mathrm{n}$ & $\begin{array}{l}\text { Share } \\
\text { "No" }\end{array}$ & $\begin{array}{l}\text { Share } \\
\text { WTP }\end{array}$ & $\dot{X}$ & M & $\sigma$ & $\mathrm{D}$ \\
\hline 4. Access to public spaces & 68 & $54 \%$ & $37 \%$ & $63 \%$ & $€ 24$ & $€ 12$ & $€ 28$ & $€ 12$ \\
\hline $\begin{array}{l}\text { Access to public spaces in relation to earn- } \\
\text { ings }\end{array}$ & 28 & $22 \%$ & $0 \%$ & $100 \%$ & $2.73 \%$ & $0.83 \%$ & $7.95 \%$ & $0.56 \%$ \\
\hline 5. Access to nature & 64 & $50 \%$ & $44 \%$ & $56 \%$ & $€ 20$ & $€ 12$ & $€ 24$ & $€ 24$ \\
\hline Access to nature in relation to earnings & 21 & $17 \%$ & $0 \%$ & $100 \%$ & $1.09 \%$ & $0.71 \%$ & $1.08 \%$ & $0.56 \%$ \\
\hline 6. Better environment & 65 & $51 \%$ & $35 \%$ & $65 \%$ & $€ 27$ & $€ 22$ & $€ 29$ & $€ 24$ \\
\hline Better environment in relation to earnings & 24 & $19 \%$ & $0 \%$ & $100 \%$ & $4.01 \%$ & $0.97 \%$ & $\begin{array}{r}11.51 \\
\%\end{array}$ & $2.00 \%$ \\
\hline 7. Better education and health care & 72 & $57 \%$ & $25 \%$ & $75 \%$ & $€ 27$ & $€ 12$ & $€ 38$ & $€ 12$ \\
\hline Better service in relation to earnings & 36 & $28 \%$ & $0 \%$ & $100 \%$ & $1.62 \%$ & $1.11 \%$ & $1.50 \%$ & $1.00 \%$ \\
\hline 8. Higher public safety & 73 & $57 \%$ & $42 \%$ & $58 \%$ & $€ 26$ & $€ 15$ & $€ 24$ & $€ 12$ \\
\hline Higher public safety in relation to earnings & 25 & $20 \%$ & $0 \%$ & $100 \%$ & $1.58 \%$ & $1.19 \%$ & $1.42 \%$ & $1.25 \%$ \\
\hline
\end{tabular}

Willingness to pay for amenities expressed by the businesses

Table 3

\begin{tabular}{|c|c|c|c|c|c|c|c|c|}
\hline Amenities & $\mathrm{N}$ & $\mathrm{n}$ & $\begin{array}{l}\text { Share } \\
\text { "No" }\end{array}$ & $\begin{array}{l}\text { Share } \\
\text { WTP }\end{array}$ & $\dot{x}$ & M & $\sigma$ & $\mathrm{D}$ \\
\hline \multicolumn{9}{|c|}{ Cracow City } \\
\hline 1. Reduced travel time & 15 & $25 \%$ & $67 \%$ & $33 \%$ & $€ 294$ & $€ 241$ & $€ 193$ & $€ 482$ \\
\hline 2. More roads in the area & 16 & $27 \%$ & $63 \%$ & $38 \%$ & $€ 73$ & $€ 30$ & $€ 93$ & $€ 12$ \\
\hline $\begin{array}{l}\text { 3a. Type of infrastructure to } \\
\text { improve }\end{array}$ & 8 & $13 \%$ & $25 \%$ & $75 \%$ & --- & --- & --- & --- \\
\hline $\begin{array}{l}\text { 3b. Fee for improved } \\
\text { Infrastructure }\end{array}$ & 12 & $20 \%$ & $58 \%$ & $42 \%$ & $€ 40$ & $€ 48$ & $€ 13$ & $€ 48$ \\
\hline 4. Larger workplace & 17 & $28 \%$ & $47 \%$ & $53 \%$ & $€ 972$ & $€ 120$ & $€ 2351$ & $€ 120$ \\
\hline 5. Access to public spaces & 15 & $25 \%$ & $73 \%$ & $27 \%$ & $€ 88$ & $€ 72$ & $€ 63$ & $€ 120$ \\
\hline 6. Better environment & 15 & $25 \%$ & $67 \%$ & $33 \%$ & $€ 113$ & $€ 72$ & $€ 114$ & --- \\
\hline 7. Higher public safety & 17 & $28 \%$ & $35 \%$ & $65 \%$ & $€ 54$ & $€ 36$ & $€ 40$ & $€ 24$ \\
\hline \multicolumn{9}{|c|}{ Zielonki Municipality } \\
\hline 1. Reduced travel time & 16 & $46 \%$ & $75 \%$ & $25 \%$ & $€ 73$ & $€ 193$ & $€ 57$ & $€ 241$ \\
\hline 2. More roads in the area & 17 & $49 \%$ & $65 \%$ & $35 \%$ & $€ 43$ & $€ 27$ & $€ 27$ & $€ 24$ \\
\hline $\begin{array}{l}\text { 3a. Type of infrastructure to } \\
\text { Improve }\end{array}$ & 15 & $43 \%$ & $80 \%$ & $20 \%$ & --- & --- & --- & --- \\
\hline $\begin{array}{l}\text { 3b. Fee for improved } \\
\text { infrastructure }\end{array}$ & 15 & $43 \%$ & $80 \%$ & $20 \%$ & $€ 56$ & $€ 38$ & $€ 56$ & $€ 48$ \\
\hline 4. Larger workplace & 19 & $54 \%$ & $63 \%$ & $37 \%$ & $€ 867$ & $€ 120$ & $€ 922$ & $€ 120$ \\
\hline 5. Access to public spaces & 17 & $49 \%$ & $71 \%$ & $29 \%$ & $€ 108$ & $€ 72$ & $€ 97$ & $€ 120$ \\
\hline 6. Better environment & 17 & $49 \%$ & $82 \%$ & $18 \%$ & $€ 74$ & $€ 72$ & $€ 85$ & $€ 72$ \\
\hline 7. Higher public safety & 17 & $49 \%$ & $82 \%$ & $18 \%$ & $€ 94$ & $€ 33$ & $€ 127$ & $€ 36$ \\
\hline
\end{tabular}

Tables descriptions

\begin{tabular}{|l|l|}
\hline $\mathrm{N}$ & - number of responses \\
\hline $\mathrm{n}$ & - share in the total number of responses per. responding to the survey \\
\hline Share "No" & - share of answers with "n" that are not willing to pay \\
\hline Share WTP & - share of answers with " $\mathrm{n}$ ", which express the willingness to pay \\
\hline $\mathrm{X}$ & - arithmetic average \\
\hline $\mathrm{M}$ & - median \\
\hline $\mathrm{D}$ & - dominant, modal \\
\hline$\sigma$ & - standard deviation \\
\hline-- & - inability to calculate, incomplete data \\
\hline
\end{tabular}


WTP for infrastructure amenities: reducing the travel time to destinations

In the light of the research, $82 \%$ of suburban households reported WTP for reduced travel time to the selected destination point. Also, residents of the city have reported WTP, but at a lower level of $61 \%$. Residents of the suburbs who reported WTP would be willing to cover costs for a shorter time to reach the destination of about $€ 24$ per month (dominant, median). Similar values were shown by residents of the city, as the dominant $€ 24$, and the median $€ 19$. This expenditure in respect to the monthly earnings of the respondents in both groups of inhabitants is: $0.95 \%$ for the city; for suburbs: $1.5 \%$ (median). However, in respect to expenditure on transport (fuel, tickets) for the city are $19 \%$ and $12 \%$ for suburbs (median). Respondents' answers also allow the assessment of the time value spent in traffic. Thus, for the suburban residents 1 minute in traffic is worth $€ 0.04$ (median, excluding fuel) while most of the respondents indicated $€ 0.02$ (dominant). The city residents responded similarly; dominant $€ 0.04$; median $€ 0.02$. It should be added, that for the suburb residents the main destinations are work and the children's school; while in the case of city residents, the destination is work and the city center.

In conclusion, the suburb residents are more likely to incur additional charges for reduced travel to selected destinations. This does not mean that the city inhabitants are not inclined to do this as well, because they show interest in shorter trips. Regardless of the level of earnings, the monthly fee for shortening the time is the same both in the city and suburbs, and it fluctuates around $€ 20$ per month. At the same time for both groups of respondents, the time spent in traffic is similar between $€ 0.02$ and $€ 0.04$ per min. regardless of the length of time spent in traffic jams. This is due to the fact that traffic formulates in the city (the area of the city, which was the subject of analysis for the area of the city) and it relates to the same extent in both groups of respondents - traffic jams definitely formulate less frequently in the suburbs. In this light, the responses are consistent.

In regards to companies, within both the suburbs and the city, a minority reported WTP for reduced time travel, which indicates that they are not interested in such an amenity. The profile of business activity conducted in the area, which is not based on transport, justify these results. Operators located in the city reported WTP are $33 \%$ of respondents, and the suburbs entities $25 \%$. The results of WTP for reducing the travel time to destinations may be an indication for the policy makers in making decisions regarding the nature and scope of investments in transportation. It should be noted that there are not the companies but the residents who show interest in shortening the commuting time. Thus, investments in shortening travel time to destinations have a good justification and social and political benefits. In addition, public demand for these investments can be presented in the form of monetary involvement: WTP by multiplying the number of the area inhabitants. Therefore, valuing the social benefit of shortening the commuting time for the residents of Zielonki Municipality (20k inhabitants) in a one year period will receive the amount of $€ 480 \mathrm{k}-680 \mathrm{k}$. In contrast to the urban fringe area of the city (115k inhabitants), this amount is $2.2-4.5 \mathrm{ml} €$ per year. Because businesses are not interested in shortening commuting times, the public authorities may consider outside road investments and the development of public transport (buses, trams, subway), which promotes and justifies a tendency to the compact of cities and prevent traffic on the one hand, and on the other hand it fits into the local spatial plans.

\section{WTP for infrastructure amenities: increasing the roads in the area}

The larger number of roads refers to both number of additional roadways, and the width and bandwidth of the existing ones. In the light of the research, $69 \%$ of the suburban population reported WTP for more roads in the area. It should be noted that this result is lower than the previous questions $(82 \%)$. At the same time the monthly fee for more roads in the area is $€ 12$ per month (median and dominant), and it is also lower than in the case of shortening the travel 
time to the selected destination point. Thus, the suburban residents tend to value higher the commuting time than the number or quality of the roads. However, the city inhabitants WTP was reported by $77 \%$ of the respondents, and this is a higher result than in the previous question, where WTP for reduced travel time was reported by $61 \%$. Interestingly, the WTP for more roads in the area is valued at the same level by the city residents as well as suburban ones, i.e. $€ 12$ per month (median and dominant). This fee in relation to earnings is similar for both groups of respondents, because for the city residents the median is $0.91 \%$ and for the inhabitants of the suburbs it represents $0.83 \%$ of the monthly earnings.

In this light, it can be concluded that the suburban inhabitants recognize the need to develop more roads than the residents of the city, but for the two groups of respondents the value of this development is the same. In regard to the question of shortening the travel time, it should be noted that this query presents a purpose or effect, but the question of more roads represents an action aimed at achieving this goal. Having this in mind, it should be noted that the residents of both areas value twice as much the result than the method of its implementation. Thus, the potential investment in local roads could go towards increasing the capacity of existing roads, rather than towards the actual construction of new road sections. At the same time, the results of WTP for increasing the roads in the area may help the process of making decisions by policy makers in terms of type of investment, which were mentioned in the WTP for infrastructure amenities: reducing the travel time to destinations. Thus, in the urban fringe and suburbs, socially justifications enable the investment in public transport and new roads that take into account the communication needs of residents more than businesses. Because in the case of businesses, both from the suburbs and the city, a minority reported WTP for more roads in the area. The answers are consistent with the previous question concerning a shorter travel time. Companies are interested in the number of low-grade and quality of roads in the area, due to their profile in the area of business specialization and in the case their activity is not based on transport. Operators located in the city who reported WTP represent $38 \%$ of the respondents, and the entities from the suburbs are $35 \%$. Therefore, companies are not interested in raising additional charges for more roads in the area.

\section{WTP for infrastructure amenities: access to or improvement of an infrastructure element}

As a part of the research concerning infrastructure, only companies from both regions were asked the question of an access or improvement of an infrastructure element. $75 \%$ of businesses from the city reported WTP for the selected item of infrastructure and it was mostly parking lots. In this case WTP is not meant as a declaration to incur additional charges, but an indication of infrastructure needs. However, they were not ready to pay for them directly, arguing that it should be guaranteed in the context of taxes paid by the company. Only $42 \%$ of companies reported WTP, and those estimated the infrastructure for $€ 48$ per month (median and dominant). However, in regards to companies from the suburbs, WTP for access to the infrastructure element was reported by $20 \%$ of the units. In the opinion of these entities there is a lack of adequate pedestrian crossings and they should be added, while one of the main access roads to Cracow is located in the area. For these companies the value of the corresponding crossings is about $€ 39$ per month ( $€ 38$ median, $€ 48$ dominant). Generally, it can be noted that the companies are aware of the needs of specific infrastructure, but they are not ready to pay. The results have territorial implications: because in this case the WTP is a measure of the needs but also the determination to access a particular item of infrastructure. It can be said that the development of entrepreneurship in both areas is not heavily dependent on the construction of a new element of infrastructure. Thus, policy and decision makers should take into account the opinion of entrepreneurs, which is due to the efficiency of public spending and it can concentrate the funds on perhaps other, broader infrastructure needs. 
WTP for spatial amenities: expansion of a functional space

An expansion of functional space is defined as the increase in surface area of the households in both regions, while in the case of companies it is a larger area of the plant. In the light of the research, $47 \%$ of households in the city study area reported WTP for larger houses. For those households the value of their housing needs is $€ 12$ per month (median and dominant), which represents $0.8-1.4 \%$ of their monthly earnings. In contrast, households from the suburbs who reported WTP for the larger houses represent $55 \%$, which is a noticeably larger share than for the residents of the city. For the residents of the suburbs the value of the bigger houses is $€ 24$ per month (median and dominant), which represents $1.0-1.6 \%$ of their monthly earnings, which is a similar level as for the city residents.

With this in mind, it can be concluded that, contrary to common thought, suburban residents are more interested in larger homes than the city residents. The value of enlargement within housing for the suburban residents is twice as high as for the inhabitants of the city. This double difference in value is due to the fact that the suburban households are wealthier than the city households - as it was indicated in the methodology section of this article. The confirmation of this conclusion is also made by the involvement of WTP in salaries, which for the residents of both areas is very close. The cases of companies, which differentiate from the residents even more, represent a reverse trend. The companies from the city are more interested in the enlargement of their plant space than companies from the suburbs. With regard to the business of the city, 53\% reported WTP for larger functional space, and the value of extra space for these entities is $€ 120$ per month (dominant and median). Exactly the same value indicates the entities located in the suburban area, however, the proportion of the reporting entities WTP is much lower and it is of $37 \%$. Generally, it can be said that for increasing the area of the plant primarily the companies from the city are willing to cover the costs, and to a lesser extent, these are the companies from the suburbs. Operators of both regions value the enlarging of their plant at the same level of $€ 120$ per month.

The territorial implications of the results of the research are different for the two areas of analysis. The urban fringe identifies the need for adequate space for running business. Proper business activity has two dimensions: it is both a larger area plant - which results from the analysis of the current point, being as well associated with infrastructure such as parking lots at the business point - as a result of responses to the WTP for access or the improvement of an infrastructure element. However, with regard to the suburbs, where more than half of the respondents would be willing to pay for a bigger house, those results can be regarded as a harbinger of increasing of urban sprawl. Given the results of the analysis, households within suburbs have a preference for living in the suburbs because of their predilection for more natural environments and, in addition, households are financially well off. Thus, colliding consumer preferences, their financial status and willingness to pay for a larger apartment can be formulated in the hypothesis that in the future such households will seek larger homes out of the city.

\section{WTP for spatial amenities: access to public spaces}

Public space in this study was understood as a compound of all kinds of places available widely that have the physical form and which can be used to satisfy the needs of stakeholders and their social networking, e.g.: shopping malls, recreational areas, public building.

In light of the research, $63 \%$ of suburban households reported WTP for access to public spaces and determined the value of such a facility for $€ 12$ per month (median and dominant). The indicated value is generally $0.6 \%-0.8 \%$ of the monthly household budget. However, in relation to the households of the city study area, $43 \%$ reported WTP for access to such space, indicating the level of access to $€ 4.8$ per month (median $€ 4$.8; dominant $€ 2.4$ ). In relation to the 
monthly earnings the indicated value of WTP is $0.5 \%$ (median, dominant).

The results indicate that for households located in the suburbs the access to public space is more valuable both nominally and relatively to earnings. The majority of suburban residents reported a WTP for access to public spaces, against minorities of the city residents.

When it comes to companies, the results are very similar to the above and indicate that $29 \%$ of companies from the suburbs reported WTP for access to public spaces, and $27 \%$ of the companies of the city expressed such a readiness. So operators on both sides of the border of the city indicate that they are not interested in raising additional charges for access to public spaces, while those who were interested value this amenity at a high level.

The results confirm that the suburbs of big cities have to deal very often with urban sprawl which takes place in this case. Polish urban sprawl is characterized by chaos in the structure of land development, and it is due to the fact that the vast majority of plots are privately owned by a relatively high price and there are no public spaces. The conclusions from the results of the analyses are addressed here mainly to policy makers in the suburbs: spatial plans should take account of public spaces, and policymakers should secure funds for their implementation. Public spaces enhance the attractiveness of the municipality, and they may cause land densification thereby preventing urban sprawl.

\section{WTP for spatial amenities: access to natural open spaces}

The above question concerning the valuation of public spaces was an attempt to access the valuation of natural open space, which can be used by the residents while enriching the landscapes of the inhabited area. This question is addressed only to the households located on both sides of the border city. The results of the analyses for the two areas are similar and indicate that $55 \%$ of the city population reported WTP for access to nature, while $56 \%$ of people in the suburbs reported the same willingness. For the residents of the suburbs the potential access to nature is worth $€ 12$ per month (median), which constitutes $0.71 \%$ of the household budget while for the residents of the city it is assessed to a value close to $€ 5$ per month (median), which represents $0.63 \%$ of the household budget.

The above presented results indicate that the communities on both sides of the border of the city do not differ and they would be ready to bear a fee for the access to nature. Despite the differences between the assessment of access to nature between the inhabitants of the city and the suburbs, the reported values are a similar percentage of the household budget. While the results for the city inhabitants are not surprising, the results of the assessment of the suburbs' residents need to be considered. Although the residents of the suburbs inhabited the areas close to the natural open spaces, the high interest in wider access to nature should be sought in their preferences. The residents of these areas settled primarily for reasons of environmental preferences and related aesthetic of the area, while the other conditions were less important. In the light of the outcome of the two studies presented, the results are consistent, and the consumer preferences towards access to nature are very strong and highly valued (Lityński and Hołuj 2015). This conclusion stems from the fact that, despite living near open areas, most households are willing to pay the additional charge for increasing the access to such areas. This conclusion may have territorial implications in the form of the spatial needs of the common policies of the city and the neighboring municipalities (and this is not the case in Poland). It's about securing access to natural open spaces (e.g. parks, green belts) for the residents.

\section{WTP for spatial amenities: higher quality of the environment}

A better environment was explained to the respondents being particularly as a higher air quality 
and lower noise pollution. Taking into account the study results, both residents of the city and suburbs reported WTP for a better environment. For both groups of respondents the WTP were reported by $65 \%$ and the value on the whole was estimated at: city $€ 22$ per month (median), which accounted for $1 \%$ of the budget; suburbs $€ 12$ per month (median), which accounted for $0.9 \%$ of household budget.

A better environment was also the subject of analysis among the companies of the city and suburbs. Companies in both regions are not interested in incurring additional charges for these amenities because WTP reported $18 \%$ of companies in the suburbs and $33 \%$ of the companies of the city.

These results are consistent with those presented above for a similar issue, which focused on access to nature. Also the requests and the justification of these results are similar. In addition, the analysis in both areas proves that there is a need to improve the environment, and the residents are willing to participate in the costs. This creates opportunities for policy makers to implement environmental solutions co-financed by the locals. The results are also the reasons for the present activities of the local authorities. The idea is that the local authorities in the analyzed area bring funding to replace the heating stoves in homes from old to new gas carbon.

\section{WTP for public service amenities: better education and health care}

In the light of the studies, suburban residents in the majority reported WTP for better access to these kinds of public services and their share is $75 \%$. Residents of these areas valuated this access for $12 €$ per month (median and dominant). That indicated fee is not more than $1 \%$ of the household budget (median 1.1\%, 1\% dominant). In contrast, residents of the analyzed area of Cracow reported WTP to $68 \%$ and they estimated the value of nearly $€ 10$ per month (median), which represents $1.4 \%$ of the household budget.

Considering the above, households with both regions are substantially interested in education and health care at a higher level. For the residents of the suburbs we observed a higher interest in better public services, but the value of better services valued by this group is slightly lower than indicated by the inhabitants of the city.

Education and health care services in the analyzed suburbs and urban fringe do not represent amenities that attract the residents to settle in those locations. For this reason, the territorial implications of the results may be related to municipal, suburban or urban fringe area development strategies. Making a better offer of these services to the urban fringe can prevent urban sprawl and attract people to settle within the city limits. However, from the point of view of the authorities of the neighboring municipality of the city one can consider raising the quality of education in local schools. High levels of education may be an element of competitive advantage over other municipalities and the reason for families to settle in the municipality. It should be noted that such strategies are implemented in the suburbs in the US (e.g. a suburb of Chicago, IL.: families are moving to the district of Stevenson High School, Lincolnshire, IL., so that children may attend this particular high school. This results in a high demand for real estate and high income tax in the municipality).

\section{WTP for public service amenities: higher public safety}

Higher public safety in the studies was defined as the derivative of the level of threat of crime and police response to this type of pathology. In regard to households of the suburbs and the city, the results indicate that $69 \%$ of the city population and $58 \%$ of the suburban population reported a WTP for raising safety in the area. For the city households an improvement of the safety is valued at $€ 12$ per month (median), which represents about $0.7 \%$ of their budget, while 


\section{Piotr LITYŃSKI}

for the households of suburbs a higher security is worth $€ 14$, which is $1.2 \%$ (median) of their budget.

However, in relation to the business of the two study areas, the results indicate that $65 \%$ of the entities from the city and $18 \%$ of the suburban subjects reported WTP for increasing safety. For the companies of the city, safety can be evaluated for $€ 36$ per month (median $€ 36$, dominant $€ 24$ ), and for those from the suburbs for $€ 33$ per month (median $€ 33$, dominant $€ 24$ ).

Thus, the results of the analysis indicate that households from both regions are interested in increasing the security in the area of residence and they would be ready to pay for it. At the same time the residents of the suburbs valuated safety higher, both in nominal terms and as a percentage of their revenue. The businesses represent diverse points of view. In their vast majority, companies of the city would be interested in enhanced security, while companies from the suburbs are situated on the other pole - they feel safe. At the same time companies of both regions valuated higher security at a similar level.

The territorial implications of the results are the same as in the case of education and health care: policy makers should adopt appropriate tasks to ensure that amenities could be a factor in encouraging people to settle in the area.

\section{Conclusions}

In large urban areas of developing countries like in Poland, there are various infrastructural and public services amenities, but the desire to achieve socio-economic development at a higher level is inextricably linked with the upgrading of these amenities. A part of the existing amenities is sufficient to the continued economic development. However, there are amenities that need to be improved, especially in areas neglected or problematic from the point of view of spatial policy - here taking into account the urban fringe areas and the suburbia. These areas require investments from the part of policy makers, but outside a valuation of financial outlays for investments there remains a social problem in their valuation, and also for the social and economic funds in this area of development.

Using an example of Cracow City and its suburbs the research attempts to estimate the value of a number of hypothetical improvements to the entities of the real economy. This demonstrates the social and economic value and justification of potential investments which are important for policy makers. At the same time the study shows differences between the neighboring entities spatially separated by the administrative boundaries of the city. It turns out that the administrative border does not differentiate companies, but it polarizes households. This is particularly noticed in the differences of their socio-economic profile.

Based on the research regarding the amenities improvements, different conclusions can be addressed to the policy makers of cities in the developing countries. So that, amenities located in the area favor and accelerate economic and social development. Reduced travel time to selected destinations is important in maintaining the momentum of economic development and it requires investments in infrastructure. But not in all cases, as these investments must go towards the construction of new roads and they do not meet always the social and economic expectations. Often, companies in these areas are not based on transport and do not require significant investments in roads. In the case of the suburbs and the urban fringe, often a better solution might be the expansion of public transport, which has social and financial reasons. At the same time, such investments are conducive to the compactness of the city and they can be a remedy for urban sprawl. The issue of the impact of amenities on the formation of urban sprawl appears in literature (Wu and Gopinath 2008), as well as in the present conducted research. It turns out that amenities in the form of a bigger house are of real interest for the residents of the suburbs, which may contribute to further urban sprawl. The increase of urban 
sprawl is justified by the lack of public space in the suburbs and by the demand for access to open spaces for which the residents have reported WTP. This diagnosis should find a response in the form of policy makers in the preparation and implementation of relevant spatial plans (e.g. parks, green belts). Residents in both urban fringe and suburbs report the need for a better environment while they are willing to participate to the costs of its improvement. This creates opportunities for policy makers to implement environmental solutions co-financed by the locals. Public services like education, health care and public safety are important amenities as incentives for the urban population to settle in a certain area but also for the area's socioeconomic development. In the light of the research results, the area of the suburbs and the urban fringe require improvements in terms of their development strategy. Such improvements can prevent urban sprawl and contribute to creating areas of specialization (e.g. education) prompting families to settle in and stimulating the local development. The development of entrepreneurship is also an important opportunity to enhance economic activities and urban growth. The needs in this field report generally on the entities from the urban fringe while they require new business areas as well as associated infrastructure (parking lots).

\section{References}

BANZHAF H. S. (2010), Economics at the Fringe: Non-Market Valuation Studies and their Role in Land Use Plans in the United States, Journal of Environmental Management 91 (3), 592-602.

BATEMAN I. J., LANGFORD I. H. (1997), Non-users' Willingness to Pay for a National Park: An Application and Critique of the Contingent Valuation Method, Regional Studies 31 (6), 571-582.

BERGSTROM J. C., READY R. C. (2009), What Have We Learned from over 20 Years of Farmland Amenity Valuation Research in North America? Review of Agricultural Economics 31 (1), 21-49.

BEYERS W. B., LINDAHL D. P. (1996), Lone Eagles and High Fliers in Rural Producer Services, Rural Development Perspectives 11 (3), 2-10.

CARSON R. T. (2007), Contingent Valuation. A Comprehensive Bibliography and History, Edward Elgar Publishing, Cheltenham.

CAVAILHES J., PEETERS D., SEKERIS E., THISSE J.-F. (2004), The Periurban City: Why to Live between the Suburbs and the Countryside, Regional Science and Urban Economics 34 (6), 681-703.

CHAY K. Y., GREENSTONE M. (2005), Does Air Quality Matter? Evidence from the Housing Market, Journal of Political Economy 113 (2), 376-424.

CHEN Y., IRWIN E. G., JAYAPRAKASH C. (2009), Dynamic Modeling of Environmental Amenity-Driven Migration with Ecological Feedbacks, Ecological Economics 68 (10), 24982510.

DELLER S. C, TSAI T.-H., MARCOUILLER D. W., ENGLISH D. B. K. (2001), The Role of Amenities and Quality of Life in Rural Economic Growth, American Journal of Agricultural Economics 83 (2), 352-365.

DIAMOND P. A., HAUSMAN J. A. (1994), Contingent Valuation: Is Some Number better than No Number? The Journal of Economic Perspectives 8 (4), 45-64.

FEINERMAN E., KOMEN M. H. C. (2003), Agri-environmental Instruments for an Integrated Rural Policy: an Economic Analysis, Journal of Agricultural Economics 54 (1), 1-20.

FULLER K., MONSON M., WARD J., MATHEWS L. G. (2005), Can Nature Drive

Economic Growth? Review of Agricultural Economics 27 (4), 621-629.

GILHESPY I. (2013), Beyond the Fringe: the Role of Recreation in Multi-Functional

Urban Fringe Landscapes, Journal of Urban and Regional Analysis 5 (2), 143-152.

GOTTLIEB P. D. (1995), Residential Amenities, Firm Location and Economic Development, Urban Studies 32 (9), 1413-1436.

GREEN D. P., BLAIR I. V. (1995), Framing and the Price Elasticity of Private and Public

Goods, Journal of Consumer Psychology 4 (1), 1-32. 
GREEN G. P. (2001), Amenities and Community Economic Development: Strategies for Sustainability, The Journal of Regional Analysis and Policy 31 (2), 61-75.

HUHTALA A. (2004), What Price Recreation in Finland? - A Contingent Valuation Study of Non-Market Benefits of Public Outdoor Recreation Areas, Journal of Leisure Research 36 (1), 23-44.

JOHANSSON P.-O. (1990), Valuing Environmental Damage, Oxford Review of Economic Policy 6 (1), 34-50.

JOHNSON J. D., RASKER R. (1993), Local Government: Local Business Climate and Quality of Life, Montana Policy Review 3 (2), 11-19.

LITYŃSKI P., HOŁUJ A. (2015), The Profile of Households Generating Urban Sprawl on the Example of Selected Area of Cracow Metropolitan Area (In Polish), in: KUDŁACZ T., LITYŃSKI P. (eds.), The Management of Space in Cities and Regions - Conditions and Directions (In Polish), Studia KPZK PAN 161, Warsaw, pp. 402-414.

MATSUOKA R. H., KAPLAN R. (2008), People Needs in the Urban Landscape: Analysis of Landscape and Urban Planning Contributions, Landscape and Urban Planning 84 (1), 7-19.

MILBURN L.-A. S., BROWN R., MULLEY S. J. (2010), '... Silver in the Stars and Gold in the Morning Sun': Non-farm Rural Landowners' Motivations for Rural Living and Attachment to their Land, Landscape Research 35 (1), 27-46.

NELSON E., UWASU M., POLASKY S. (2007), Voting on Open Space: what Explains the Appearance and Support of Municipal-Level Open Space Conservation Referenda in the United States? Ecological Economics 62 (3-4), 580-593.

NOONAN D. S. (2004), Valuing Arts and Culture: A Research Agenda for Contingent Valuation, The Journal of Arts Management, Law, and Society 34 (3), 205-221.

PARYSEK J. J. (2010), Urban Policy in the Context of Contemporary Urbanization Processes and Development Issues of Polish Cities, Journal of Urban and Regional Analysis 2 (2), 33-44.

PEARCE D. (1993), Economic Values and the Natural World, Earthscan, London.

REDFEARN C. L. (2009), How Informative are Average Effects? Hedonic Regression and Amenity Capitalization in Complex Urban Housing markets, Regional Science and Urban Economics 39 (3), 297-306.

WALSH R. (2007), Endogenous open space amenities in a locational equilibrium, Journal of Urban Economics 61 (2), 319-344.

WALTERT F., SCHLÄPFER F. (2010), Landscape Amenities and Local Development: A Review of Migration, Regional Economic and Hedonic Pricing Studies, Ecological Economics $70(2), 141-152$.

WINPENNY J. T. (1995), The value of the environment. Economic assessment methods (In Polish), Polskie Wydawnictwo Ekonomiczne, Warsaw.

WU J. J., GOPINATH M. (2008), What Causes Spatial Variations in Economic Development in the United States? American Journal of Agricultural Economics 90 (2), 392 408.

ŻYLICZ T. (2004), Environmental Economics and Natural Resources (In Polish), Polskie Wydawnictwo Ekonomiczne, Warsaw.

Initial submission: 07.04.2015

Revised submission: 17.06 .2015

Final acceptance: 22.06.2015

Correspondence: Department of Regional Economy, Faculty of Finance, Cracow University of Economics, Rakowicka 27, 31-510, Cracow, Poland

E-mail: litynskp@uek.krakow.pl 